\title{
Informal Land Rights and Infrastructure Retrofit: A Typology of Land Rights in Informal Settlements
}

\author{
Mahsa Mesgar *(D) and Diego Ramirez-Lovering \\ Monash Art Design and Architecture, Department of Architecture, Monash University, \\ Caulfield East, VIC 3145, Australia; diego.ramirez@monash.edu \\ * Correspondence: mahsa.mesgar@monash.edu
}

Citation: Mesgar, M.;

Ramirez-Lovering, D. Informal Land Rights and Infrastructure Retrofit: A Typology of Land Rights in Informal Settlements. Land 2021, 10, 273. https://doi.org/10.3390/land10030 273

Academic Editor: Chris Huggins

Received: 8 February 2021

Accepted: 27 February 2021

Published: 7 March 2021

Publisher's Note: MDPI stays neutral with regard to jurisdictional claims in published maps and institutional affiliations.

Copyright: (c) 2021 by the authors. Licensee MDPI, Basel, Switzerland. This article is an open access article distributed under the terms and conditions of the Creative Commons Attribution (CC BY) license (https:// creativecommons.org/licenses/by/ $4.0 /)$.

\begin{abstract}
Informal settlements represent a challenging operational context for local government service providers due to precarious contextual conditions. Location choice and land procurement for public infrastructure raise the complicated question: who has the right to occupy, control, and use a piece of land in informal settlements? There is currently a dearth of intelligence on how to identify well-located land for public infrastructure, spatially and with careful consideration for safeguarding the claimed rights and preventing conflicts. Drawing on a case study of green infrastructure retrofit in seven informal settlements in Makassar, Indonesia, we classify the informal settlers' land rights into four types: ownership, use, control, and management. This exploratory study uses a typological approach to investigate the spatial dimension of land rights in informal settlements. We introduce non-registrable land interests and the partial, dynamic, and informal land use rights that impact the land procurement for infrastructure retrofit. We also create a simple spatial matrix describing the control/power, responsibilities and land interests of different stakeholders involved in the location decision making for public infrastructure. We argue that without sufficient understanding of non-formal land rights, land procurement proposals for the public infrastructure upgrades can be frustrated by the individual or group claims on the land, making the service provision impossible in informal settlements.
\end{abstract}

Keywords: informal settlements; morphological study; land tenure; land rights; infrastructure retrofit; green infrastructure; WASH

\section{Introduction}

Informal housing, which is often part of overcrowded, poorly serviced, and unhealthy neighbourhoods, has proven to be the only affordable housing choice left for a significant part of the population in Global South [1]. In the absence of regulated and planned provision of upfront necessary infrastructure-i.e., water supply, sanitation systems, footpaths, and drainage - these services have to be retrofitted after housing has been built, into unplanned and dense conditions [2]. Local governments, often through the support of international aid initiatives, have tried to address this in several ways, such as on-site sanitation provision and other forms of decentralised wastewater treatment (i.e., drainage, collective septic systems). However, except for a small number of successful examples [3-5], these initiatives have increasingly failed to be sustained over time [6].

New approaches for implementing decentralised wastewater treatment systems have emerged that allow for effective and affordable sanitation infrastructure expansion to informal settlements. Examples of these approaches are green infrastructure or naturebased systems-i.e., planted soil filter beds or constructed wetlands $[7,8]$. However, some fundamentals need to be resolved to make these new approaches feasible and sustainable in an informal urban context. First and foremost, acquiring the land is a substantial challenge. From this standpoint, any physical intervention must simultaneously safeguard the claimed land rights, prevent or manage unsettled or new conflicts, and secure available 
and sufficient space for infrastructure. Securing the land for infrastructure retrofit is a particular challenge for informal settlements due to a combination of spatial and nonspatial factors:

- the complex nature of customary and non-formal tenure arrangements which represent a different operational context for local governments, particularly service providers [9-12];

- dense settlement patterns characterised by a lack of publicly owned land for services [2,13-15], as land is not often set aside by informal settlement dwellers for these functions and through incremental development, dwellings eventually occupy all available land in these communities;

- unstable environmental conditions as a result of a lack of formal planning and building on land unfit for housing, such as high levels of exposure to flooding and its devastating impacts [2,16-18].

These conditions are common in the informal settlements of Indonesian cities, presenting additional challenges for physical settlement upgrading and provision of infrastructures [12]. Unless we develop a deep understanding of these complex contextual conditions, land procurement proposals for public infrastructure retrofit can be frustrated by individual or group claims on land, making service provision impracticable in informal settlements. This paper intends to contribute to this knowledge gap through a case study of informal settlements in Makassar, Indonesia.

\section{Literature Review}

A careful analysis of urban morphological elements and ordering rules governing them, as the raw-material for design, can inform good urban design and potentially help urban designers to make better design decisions $[19,20]$. Within the context of informal settlements, any intervention (including basic infrastructure) will gradually be integrated into the existing and future pattern of land use, appropriation and development. Therefore, the potential for these elements to be maintained and sustained over time depends on the extent to which they support necessary daily actions-i.e., accessibility, social interaction, and livelihood activities. Intervention feasibility and sustainability are also contingent on how the pattern of existing relationships and rules governing the land-i.e., ownership right, rights of control, use, and management-are respected in design proposals [21,22].

Recognising and safeguarding non-formal land rights have been the subject of extensive research over the past few decades. We identified two main literature streams in this area. The first stream explores rights, restrictions, and responsibilities (RRRs) related to the interests in land and focuses on developing alternative approaches to land use and land tenure registration along the continuum of land rights $[10,23,24]$. The most significant research has been carried out by the Global Land Tool Network (GLTN). The network and its partners advocate socio-technical innovations and the application of pro-poor land tools in settlement upgrading initiatives to shift the focus away from individual titling to a more inclusive approach to securing land rights for all $[25,26]$. Several significant research outputs have been produced by this group, such as the Social Tenure Domain Model (STDM) ([27-29]; Land Administration Domain Model (LADM) [30-32]; pro-poor land recordation tool (PPLRT) [33]; community-based land registration and participatory mapping (e.g., GPS supported community mapping, Citizen's Cadastre) [34-37].

The second literature stream explores the people-to-land relationships in rural communities and discusses the social, economic, and ecological implications of existing land rights in agrarian communities [38]. Recognition and protection of dynamic, multiple claims on a single piece of land are continuing concerns for scholars in this group [38]. For example, Food and Agriculture Organisation of the United Nations (FAO) (2002) presented four types of individual and collective interests relating to land tenure and use, which can cause disagreement and dispute over land rights. These include: overriding interests (i.e., allocation or reallocation of land through expropriation); overlapping interests (i.e., several parties enjoy different rights in the same parcel, such as individual lease arrangements and 
right of way); complementary interests (i.e., sharing the land among different parties for complementary uses such as growing crops, temporary retail kiosks and access roads); and competing interests (i.e., contesting same interests by different parties in the same parcel). These land interests must be carefully identified and protected to safeguard sustainable rural livelihoods [39]. The overlapping and complementary land interests are also present in urban informal settlements, particularly satellite settlements and those located in preurban areas. However, most studies have excluded partial, dynamic, and informal seasonal land use rights and exclusively focused on the overriding and competing interests and registrable rights (e.g., title registration and deed registration [40]). Very little is known about how the presence of these often non-registrable interests can impact the feasibility of land procurement for infrastructure retrofit. Additionally, the spatial dimension of land rights is often underestimated [41]. Consequently, the proposed frameworks and tools are often far too legal and policy-oriented to be used directly in infrastructure retrofit practice.

In this paper, we adopt a typological approach to investigate the spatial dimension of both registrable and non-registrable land rights in informal settlements. The rest of the paper is structured as follows. Following a brief description of the research methods, we study elements of the spatial layout of settlements in the case study area, which are pertinent to location choice for infrastructure. We then explore different rules governing the space and a range of rights held or claimed by individuals, community, and local authorities. The paper proposes a spatial typology accompanied by a "Powergram". The "Powergram" concept developed by McGlynn and Murrain (1994) shows the control/power, responsibilities and interests of different stakeholders involved in the development processes [42].

\section{Methodology}

According to Kropf (2017), urban morphological studies can be divided into two main categories based on their purpose and specific applications including general informative and explanatory, and practical, evidence-based studies [43]. The first category encompasses most morphological studies about informal settlements and aims to thoroughly explain the unplanned processes of formation, transformation and consolidation of the settlements and deepen understanding of self-organised urban order [2,15,22,44-48].

The second category of morphological studies, comprising practical, evidence-based studies, partially contributes to design practice and policy formulation. Research outputs of scholars in this category are often used as evidence to devise planning policies based on the pattern of growth and transformation of settlements. A small number of studies have also tried to translate this understanding to design guides based on the simulation of the incremental transformation processes in unplanned settlements [49-51].

While the studies from both categories provide a rich basis for investigating informal settlements, knowledge of using these morphological studies in practice for better infrastructure retrofit is limited. This paper aims to introduce a spatial concept for classification of available spaces for green infrastructure intervention in informal settlements.

The central principles characterising morphological studies include an investigation of particular elements of the urban form, identifying their position within a configuration, and uncovering the patterns of order, relationships, and associations governing them $[19,44,52,53]$. By adopting a typological approach $[20,43,54,55]$, this paper takes the form of a case study of green infrastructure retrofit in seven informal settlements in Makassar, Indonesia. We focus on location analysis for the Blackwater treatment infrastructure components in nature-based wastewater treatment systems that demand more space (land) and have a higher impact on land use (i.e., wastewater treatment wetlands, and improved pathways with underground collection services such as pressure sewer system and communal septic tanks) $[8,56]$. The aim here is to deconstruct the spatial layout of these settlements to investigate those spatial relationships and governing rules that are critical for infrastructure retrofit. The spatial inquiry includes considering pre-implementation concerns-i.e., finding the space and land procurement proposals - and implementation and operations concerns, including ongoing access to infrastructure for maintenance and repairs, resiliency 
to environmental threats and physical transformations of informal settlements. Although we limit the research scope to a specific type of infrastructure, the findings may offer insights into the location choice and land procurement for other types of basic infrastructure such as water and wastewater infrastructure, roads, and schools.

The decentralised, nature-based wastewater treatment systems appear to be an alternative, cost-effective solution for expanding essential infrastructures to informal settlements, particularly where conventional service delivery approaches fail to respond to sanitation improvement demands $[8,56]$. However, a range of spatial and environmental considerations need to be met in terms of sustainable operation, maintenance demands, and space requirements [56].

This study's key data collection methods include observation, mapping, and interviews with representatives from the local government agencies-including The Spatial Planning Unit, Regional Development Planning Agency (BAPPEDA), Public Works Unit, Makassar's Land Agency, and National Land Agency (BPN). The components of this morphological enquiry-i.e., communal access roads, outdoor spaces and their governing rules, can be generally mapped and analysed without conducting in-depth interviews with the informal dwellers. This morphological study must be considered as an analytic tool to aid the bottom up, community-driven approaches to infrastructure provision. Further ethnographic research is needed as a part of co-designing infrastructure and before developing land procurement proposals, to gain a detailed insight into the social, religious, and political dynamics governing the land and its use in each settlement.

Availability of data and being involved in the same infrastructure upgrading project has been the key case study selection criteria. The selected settlements have much in common in terms of location, sharing similar infrastructure needs, land tenure and tenure security. Overall, the case study involves 316 dwellings, enjoying a degree of de facto tenure security and located in highly consolidated informal settlements in Makassar's pre-urban areas. The related data have been collected from various sources, including high-resolution satellite images, Google Earth maps, field data collection, and government documents.

\section{Analysis and Results}

Makassar, also known as Ujung Padang, is the administrative capital of Indonesia's Sulawesi island and the country's fifth-largest urban centre. The area's economic growth resulted in rapid rural-urban migration and the rapid expansion of informal communities in the city. In many cases, these settlements enjoy an acceptable degree of de facto tenure security. However, access to essential services such as sanitation infrastructure (as a basic human right) is limited. Local government agencies only deliver sanitation infrastructure on public land (as registered by the Department of Public Works) $[57,58]$. This ensures the infrastructure can be operated and maintained, and any legal uncertainties associated with informal land tenure arrangements can be avoided. In the meantime, traditional planning processes rarely accommodate upgrading initiatives that allow for viable solutions for the growing and immediate demand for sanitation infrastructure in these settlements. Except for those communities located in hazard-prone areas, where preventing and mitigating risk is not possible, most of the existing settlements can be upgraded in the same location. However, there is a dearth of knowledge on spatial planning for the retrofitting of infrastructure into informal settlements, and therefore, there is a need for alternative modes to servicing these communities.

\section{Which Aspects of Urban Form Are Important for Infrastructure Retrofit?}

In addition to land tenure considerations, different spatial conditions and configurations can impact the feasibility of land procurement, the sustainability of the infrastructure, and the overall benefits received by communities from the service delivery. In the following section, four types of roadways and three types of outdoor spaces are identified and eventually classified in a typology of spatial configurations based on qualitative characteristics and the spatial relationship between them that impact the location-choice for infrastructure. 
The first essential elements are communal access roads. Access roads including streets and alleyways have two physical roles that impact the land procurement for infrastructure provision and upgrading initiatives: streets as circulation routes, and streets as public spaces [59-61]. We classify the access roads into public streets, semi-public alleyways, and semi-private alleyways. Together these form a network that provides access to dwellings. In addition to the rights of control, use, and property rights, these spaces are ruled by "right-of-way" and "right-of-privacy" [27,62,63]. The category presented here offers a variety of types, scales and spatial configurations that are observed in the case study area:

- Public streets (Figure 1a) can be formal or informal. In contrast to formal streets that are controlled by planning regulations and public authorities [14], informal streets are a manifestation of how circulation and access are shaped and governed outside the regulatory order and by the communities [64,65]. Informal access roads often exhibit "fractal geometric qualities" [46] and are formed as a result of informal subdivisions of land (mostly agricultural land) over time.

- Semi-public alleyways show a less permanent character comparing to the public streets. These may alter, reform or disappear in the process of settlement consolidation $[45,53]$. In more consolidated settlements, these alleyways may guide the future planning for the formalization initiatives and be the target for upgrading and improvement. In contrast to public streets, semi-public alleyways (Figure 1b) provide access to a smaller group of houses. As a result of their reduced scale, these allow a different degree of social interaction, use and control rights over the space.

- Semi-private alleyways (Figure 1c) are circulation and access routes shaped by individuals and a small group of households (often less than five households). This type also belongs to a secondary network of pathways formed in the subsequent stages of settlement growth and consolidation and resulted from further land subdivisions over time. Semi-private alleyways provide "right-of-way" and are critical for protecting the households' use rights to access their property or land [27,63]. For Indonesian cities, it is the responsibility of the head of urban communities (Kelurahan) to ensure that all households have access from their dwelling to roadways.

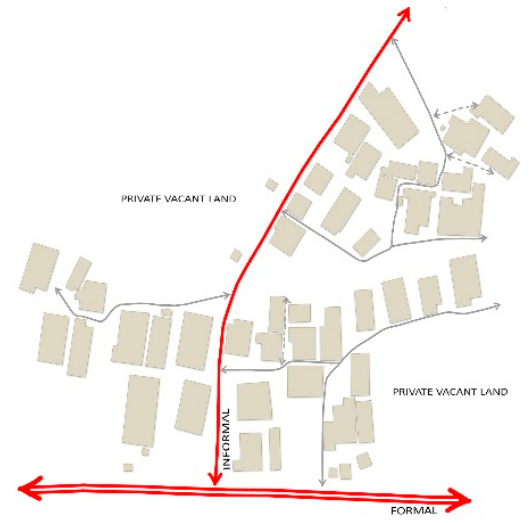

(a)

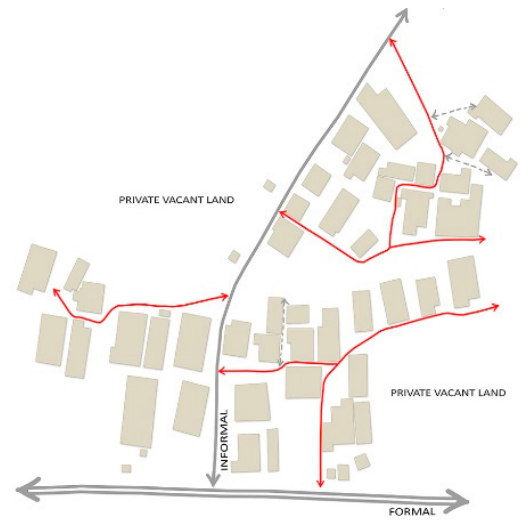

(b)

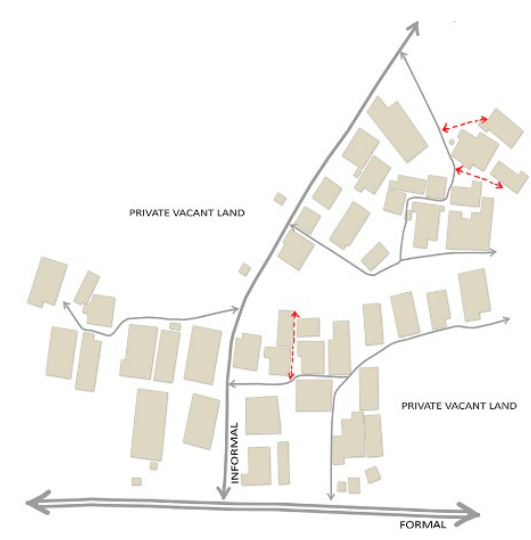

(c)

Figure 1. From left to right the red line demonstrate: (a) public streets (formal and informal); (b) semi-public alleyways; (c) semi-private alleyways in the spatial layout an informal settlement in Makassar.

The provision of dedicated outdoor public spaces in informal settlements is low, and streets often accommodate public space functions [66]. Therefore, location decisions for infrastructure retrofit must be made responsibly, ensuring that the introduction of new physical elements (i.e., green infrastructure components such as constructed wetlands) will not obstruct those functions. Under the temporary and contractual arrangements, the collective use of private outdoor spaces is also an offset against public space deficit in informal settlements. In this paper, we use the position of outdoor spaces in relation to the 
buildings and street network of settlements as a morphological principle for classification of outdoor spaces. The following definitions are intended to outline the most relevant attributes, identified for each type of outdoor spaces in cases study area.

- Frontage spaces (Figure 2a) are defined as the mediating zone or interstitial space [48] between the public face of buildings and access roads (alleyways or streets). Depending on their interface type with alleyways and their composition in the spatial layout of the settlement (i.e., the type of access-road that informal structures face) frontage space can have different forms (setback, aligned, set forward) [46], character and function. Based on their physical form, location, and function, they can secure different degrees of rights (use, control, management) for their immediate residents. Different forms of frontage spaces identified here include front setback, front yard, and cut-through plot frontages. Additionally, leftover spaces can be attached to the frontage spaces where formal streets exist. These narrow strips of space can also be located apart, on the other side of streets, where formal roads scatter the settlement. These leftover spaces are often used and controlled by the surrounding dwelling units.

- In-between spaces (Figure 2b) are defined as intermediate spaces between dwellings. This type of space can be in the form of side yard setbacks, particularly in settlements with lower building density, or can take the form of narrow spaces shared between dwellings. The latter are often used as storage space or for circulation. Within the dense informal settlements with limited outdoor spaces, these intermediate spaces are an essential element to provide access to dwellings.

- Inner spaces (Figure 2c) are defined as spaces located at the back of houses and are often used for waste dumping or as backyard gardens planted with grass or trees. In terms of spatial configuration, these spaces can be in the form of rear yard setbacks or backyard spaces. Underutilised backyard spaces are often used to expand existing houses or develop secondary buildings with minimal setbacks to allow circulation. This category also includes vacant lands and open spaces that are not used as a communal access road and are not classified as frontage or in-between spaces. Land procurement and intervention opportunities in this type depend on space's location within the spatial structure of the settlement. Backyard spaces are often unsuitable for intervention. As demonstrated in Figure 3, the three types of outdoor spaces may be linked to the network of access roads in different ways.

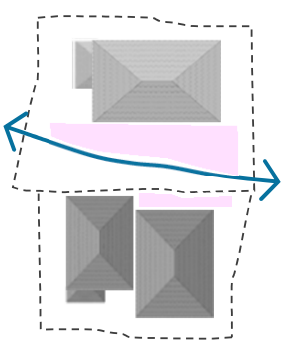

(a)

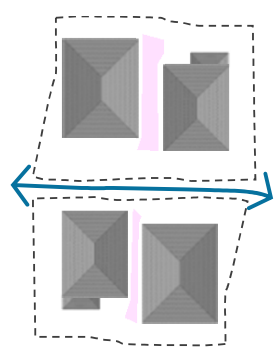

(b)

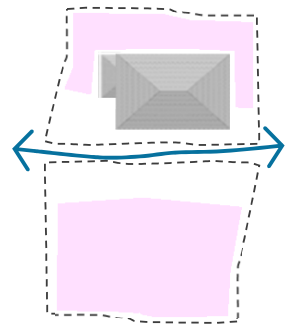

(c)

Figure 2. Different forms of outdoor spaces (from left to right): (a) frontage spaces; (b) in between spaces; (c) inner spaces.

Three fundamental prerequisites need to be met to ensure the feasibility of any intervention in informal settlements. First, adequate space in suitable locations must be available and fit for the infrastructure's technical and spatial requirements. Second, the land must be publicly available or have the potential to be acquired through a set of formal or informal tenure arrangements. Third, a collective decision about the location of infrastructure and effective land procurement strategies must be reached by establishing inclusive, participatory processes, gaining the community's trust and giving a voice to all right-holders in the settlement. "Publicness" of the space for retrofitting infrastructure, must be considered along ownership lines together with control and use boundaries. With this understanding, 
the next step in our study is to consider how land in informal settlements is governed. It is beneficial to first investigate the legal and contractual rules governing the land in informal settlements to understand the nature of infrastructure retrofit challenges. This includes an investigation of a set of individual and collective rights-i.e., ownership, control, use, and management-governing the spaces. We will briefly explain these governing rules, before taking a closer look at their role in each space, and resulting opportunities and challenges raised for infrastructure retrofit.
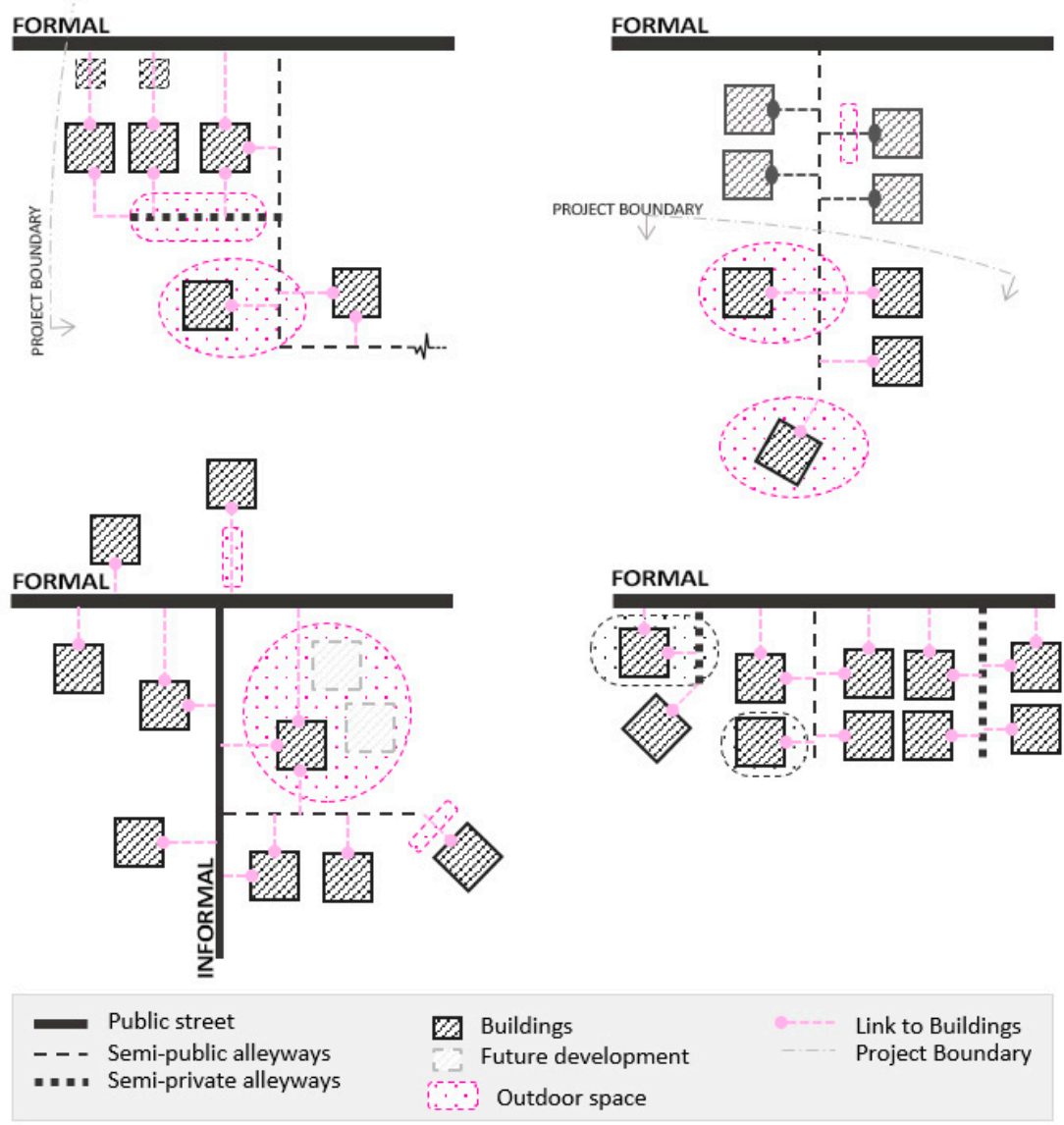

Figure 3. Spatial configuration of outdoor spaces in relation to access roads.

\section{Discussion}

\subsection{What Are the Rules Governing the Land in Informal Settlements?}

Ownership, defined here as the "legal status of a place" [67], is one of the principal measures to evaluate the urban spaces in terms of availability for public use. The legal ownership provides the most substantial level of control that can be gained through the legal occupation of the land-i.e., ownership, leasehold/rental. Where the legal ownership is not an option, de facto rights obtained through long-term occupancy can also underpin the claimed ownership rights. Thus, customary and non-formal tenure arrangements can create a complex pattern of rights.

The legal and spatial determination of rights is a challenge for informal settlements. Legal determination refers to the legitimacy of available documents (records or pieces of evidence). In contrast, spatial determination refers to how the spatial boundaries are clearly defined within the legal documents or marked on the ground. Considering the expensive cost of land boundary surveying the boundaries are often blurred.

Fluid boundaries between public-private spaces present opportunities in informal settlements-i.e., shared use and the spatial exchanges in response to residents' everyday needs such as creating access-roads. However, the perceived publicness of space does not 
make it necessarily available for public infrastructure. Any permanent changes to outdoor spaces and access roads (such as infrastructure retrofit and road improvements) require undertaking long and uncertain land acquisition processes and the transfer of private ownership to city authorities (even though the land is used publicly).

In addition to the ownership boundaries, there are other subtle and often invisible boundaries that must be considered in the location choice for infrastructure $[67,68]$. These invisible boundaries determine how space is controlled, used and managed by different individuals or groups.

Perhaps one of the most critical types of invisible boundary that carries considerable weight in the location choice for infrastructure retrofit, are boundaries of control rights. Kropf (2017) defines "control" as an established relationship between an "agent" (a person or a group) and the area of land that is under their control [43]. This control is exercised through the physical occupation or through a set of agreed, stipulated, or generally accepted codes. The right of control is not synonymous with ownership rights.

Individual or "collective" control over land can be exerted outside of the property boundaries through informal or formal codes and regulations (e.g., right of way, right of privacy) $[20,46,69]$. In the absence of state-owned public spaces, the location of land and the underlying pattern of control is a significant determinant of the feasibility of the upgrading and retrofitting infrastructure.

In addition to invisible boundaries of control, "soft controls" [70,71] may also be expressed spatially and physically through a set of symbolic manifestations. An example of this is elevated surfaces in the frontage spaces to demonstrate the control over the boundary-less land $[2,46,50]$. Soft control and perceived control rights can overstep the ownership boundaries so people can privatise part of the public realm without holding ownership rights (see Figure 4).

The degree of individual or collective control rights contributes to how a variety of stakes are granted and perceived in a particular space [72]. In informal settlements, the control rights can be "conditional" which means its exercise depends on specific circumstances-e.g., the right of control exercised by city authorities for conflict resolution in the case of individual encroachments on the right of way.

Planners and designers will also need to consider the rights of use governing the outdoor spaces and alleyways if they have to make a location choice for the public infrastructure outside of the state-owned boundaries. "Use" of space contributes to the nature of benefits that space provides and who benefit from them. The right of use encompasses informal codes and arrangements that regulate the individual activities in a particular space-i.e., use the land or its attributes [72]. Right of use not only includes using the land for access or temporary structures (e.g., kiosks, street furniture or temporary roofed spaces for gatherings) but also includes land use for plantation or crops, and green spaces controlled or used by individuals or groups for specific uses (such as medical plants, plants for food, plants for ornamental purposes and shading).

Donor-driven upgrading projects tend to avoid any changes in land use to ensure location choice for infrastructure can happen smoothly without going through lengthy and costly processes of land acquisition and compensation agreements. Therefore, the available land is often limited to the areas where no structure or income-generating activities occur or are planned. In this regard, recent morphological studies of increments of change in informal settlements provide an invaluable resource for evaluating the changes and transformation of the use of space over time $[20,46,48]$. Although the detailed analysis of incremental change patterns in outdoor spaces is essential for infrastructure sustainability and maintenance considerations, this topic falls outside of this paper's scope.

In addition to the set of rights (ownership, control, use) explained above, it is also essential to know how the outdoor spaces and alleyways are managed and maintained. This understanding reinforces a better-managed delivery and long-term maintenance of public infrastructure. Here, "management" refers to day-to-day maintenance of the outdoor spaces [67]. In informal settlements, this is often provided by individuals and household 
groups in the same community and is supervised by community groups. For example, in Makassar, the heads of Rukun Warga (RW), neighbourhood units, and Rukun Tetangga (RT), community units, are responsible for liaising between city authorities and residents. Where the partial upgrading project exists (such as road improvement or improved drainage) local government often have the ultimate responsibility and authority over the space and its attributes (including provided infrastructure). However, as local governments often neglect long-term maintenance, households may collectively contribute to the upkeep of public infrastructure-e.g., paving public alleyways, repairing public water taps, and cleaning drains. Thus, private management of public amenities and public spaces often take place in informal settlements. However, the provision of public infrastructure in private land is impracticable [3,73-76], unless a set of alternative tenure arrangements exist to safeguard settlement dwellers' agency over the land (i.e., land borrowing arrangements).

\subsection{How the Control, Use and Ownership Rights Are Distributed Spatially?}

The degree of control and use rights depends on the type of space and location within the spatial layout of settlements, which can impact the suitability and fitness of land for public infrastructure. For example, frontage spaces having immediate proximity to streets and alleyways provides a better location for infrastructure (particularly shared and communal elements) due to maintenance and operation requirements and the importance of easy access to the infrastructure. However, due to informal subdivisions and the often unclear land boundaries within informal settlements, there is a blurring of private and public spaces. Where the land plot is situated in the immediate proximity of a public street, ownership boundaries are to some extent detectable as public streets are often oriented to demarcate and protect private plot boundaries. However, excepting the frontage spaces attached to state-owned streets, the edge of the road may not be a legitimate and valid indicator of the land's boundaries and publicness. Likewise, being used for public purposes cannot promise the public status of land in terms of tenure. Therefore, the determination of where the private ownership, control, and use boundaries end and where the public boundaries begin is a challenge for informal settlements. At the same time, such awareness is imperative for location choice for infrastructure.

The position of frontage spaces in the spatial layout of settlements and the level of settlement's spatial consolidation determine how households establish and delineate the spatial extent of control and use rights outside of their property ownership boundaries. As we move up in the hierarchy of alleyways, the contractual and perceived control rightsclaimed through frontage spaces-might be contested by the needs, interests, and claimed rights of a web of different stakeholders and actors involved. For less consolidated parts of the settlements, frontage spaces significantly impact configuration and reconfiguration of alleyways and secondary network of pathways over time. As a part of these spatial transformations, the patterns of use, control and ownership rights can also alter accordingly. For example, frontage spaces can transgress the property ownership boundaries [46] in the form of a porch or a levelled platform, and extend the boundaries of control over the space outside the ownership boundaries. These softly controlled spaces can be further converted to become a roofed space or a new room, as long as the rights held by their neighbours and the surrounding community are respected. These physical changes will enable the household to make more substantial control and ownership claims based on occupation over time, and eventually obtain ownership over that piece of land. Understanding these dynamics is fundamental to location choice for infrastructure retrofit, both in terms of decision-making about land procurement strategies and sustainability and maintenance considerations.

Likewise, acquired use rights in and around frontage spaces are contingent on their position within settlements' spatial configuration. In more consolidated parts of settlements, frontage spaces may accommodate income-generating activities. These edge-oriented commercial activities can take different forms such as temporary kiosks or small shopsparticularly if frontage space faces public streets. In the former case, use rights are extended 
outside of the ownership boundaries through occupying a part of public and semi-public alleyways. In denser settlements, frontage space can also contribute to the movement network to compensate for the inefficient street network.

Front setbacks and front yards may provide space for public functions. These include social gathering, events, and household production activities-e.g., food preparation, drying crops, growing plants, and material storage, mainly where the verandas and front porches exist $[50,77,78]$. Through these activities, the boundaries of use rights may overstep ownership boundaries through the temporary and periodic occupation of the alleyways. Any physical intervention in space such as infrastructure retrofit is likely to have significant repercussions on land use and the livelihoods of people using those spaces; therefore, careful evaluation and recognition of these rights are vital in developing a feasible land procurement proposal.
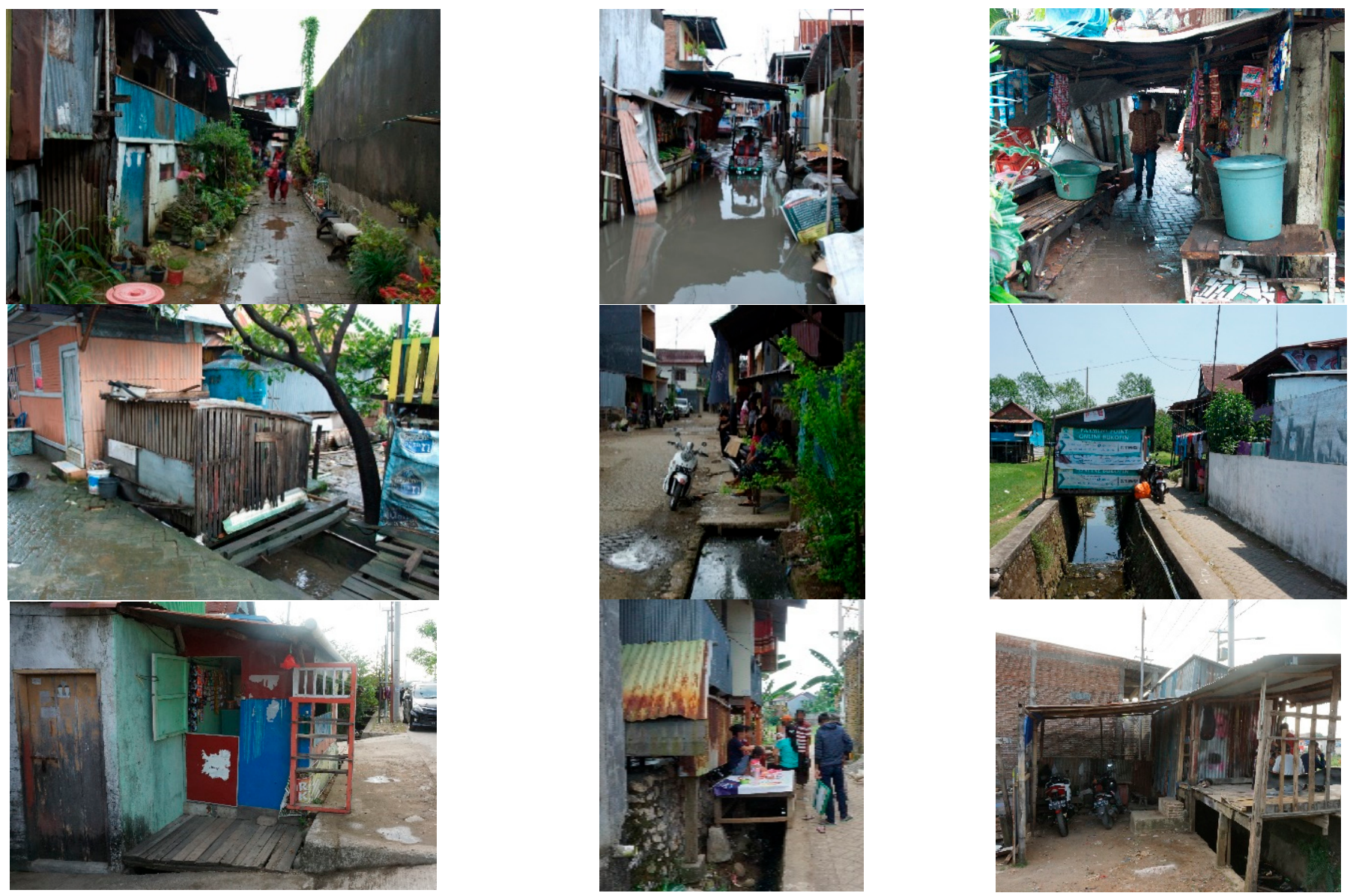

Figure 4. Control and rights can overstep the ownership boundaries to let people privatise part of the public realm without holding ownership rights. first raw: edge oriented commercial activities; second and third raw: encroachment over the government provided drains and formalised canals; Photos: Revitalization of Informal Settlements and their Environment Programme (RISE) Archive.

Compared to frontage spaces, the in-between spaces, that are narrow and constrained, have spatial disadvantages that constrain the intervention. In settlements with lower building density, wider space in side-yard setbacks may accommodate space-consuming infrastructure elements. However, these spaces are exposed to incremental, horizontal extensions. As space shrinks over time, access to the infrastructure for maintenance and repairs becomes restricted, while the risk of damages to the infrastructure from new constructions increases. Likewise, the set forward additions can obstruct the natural light and ventilation, essential for planted soil filter beds and wetlands. 
Since the land plot boundaries are not marked, in-between spaces tend to be delineated from both sides, creating more conflict over the ownership boundaries. Depending on the location within the settlement's spatial structure, these interstitial spaces can be under different degrees of control from surrounding households. If these spaces function as pathways, allowing access to a group of dwellings, the right of control is shared between households who access their houses through this space. This collective right of control is rarely accompanied by the motivation for greater care for the physical quality of the space, making in-between space the least maintained sections of the spatial layout of the settlements (see Figure 5).

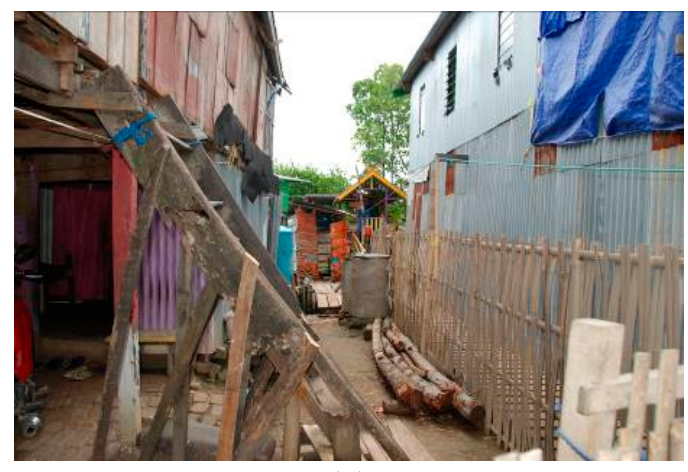

(a)

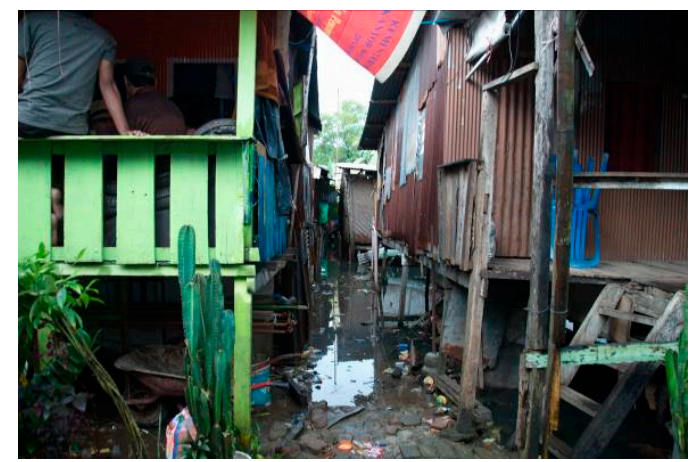

(b)

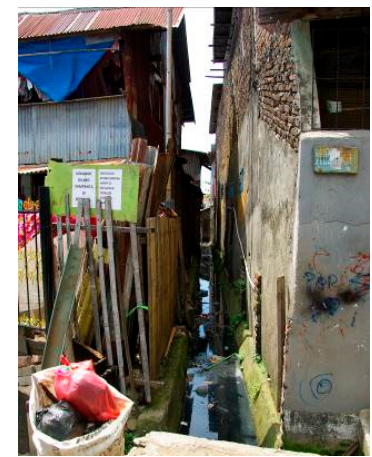

(c)

Figure 5. Different forms of in-between spaces (from left to right): (a) side yard setbacks with clearly marked ownership boundaries; (b) in-between spaces shared for access, under collective use and control rights; (c) in-between spaces; Photos: RISE Programme Archive.

As any changes in these spaces can thoroughly alter or eliminate the access to individual dwellings (Ribeiro 2006), the conditional control is often given to the city authorities to intervene in the case of potentially damaging physical alterations to the existing buildings. For example, in Makassar, the Lurah (sub-district head) and his subordinate units-i.e., heads of Rukun Warga (RW) and Rukun Tetangga (RT) units, play a mediating role in conflict resolution and are responsible for protecting semi-private alleyways from encroachment by private interests. Therefore, while these spaces belong to individual dwellings and are properties of individuals, they may also be under the city authorities' conditional control.

By contrast, inner spaces (see Figure 6) are underused areas that allow for incremental occupation through infill subdivision or extensions to existing dwellings [48]. For boundary-less spaces, ownership rights can be asserted by storing temporary construction materials, implying the construction of new structures (temporary or permanent) in the near future. Vacant rear-yard setbacks and cut-through inner spaces, particularly those proximal to public access roads, may be used periodically for the community gatherings and life events, such as weddings and funerals. However, this collective use right is limited. Therefore, land procurement for public infrastructure is conditioned to safeguarding the ownership rights of individuals along with collective use rights secured by the community.

Land contribution from owners of unoccupied land plots is often limited. However, such plots need to be included in the design process to ensure the servicing capacity of provided infrastructure accommodates future subdivisions and developments, and new dwellings can get connected to and serviced by the infrastructure. 

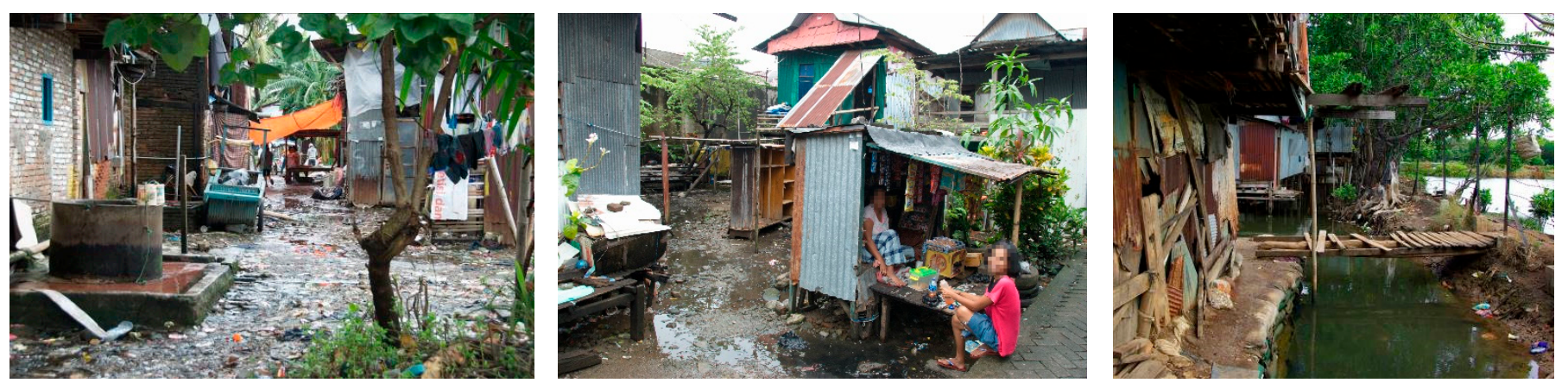

Figure 6. Different forms of inner spaces; photos: RISE Programme Archive.

In addition to local authorities and informal dwellers, landholding groups can also control land in informal settlements in several ways. They may own land plots within and around settlements or enjoy general power to control the land, often supported by local governments for development purposes. Their presence also influences acquiring land for infrastructure. In this way, they may facilitate the infrastructure provision through donating small pieces of land (often leftovers), while on the other hand, they may discourage community participation. The reason for this is no mystery. As landholding groups evince interest in the informal settlers' land, the settlers fear losing their only secured asset, making them reluctant and wary of any changes that potentially influence their control over land.

Based on this understanding, a spatial typology matrix is introduced (see Figure 7). This typology is organised based on the spatial relationships between morphological elements (outdoor spaces and communal access-roads) and how these are spatially linked and governed by a set of rights secured by different stakeholders. The settlements in our case study have a degree of de facto tenure security. Of course, the evaluation of the spaces in term of their governing rules (ownership, control and use rights) and the Powergram of main stakeholders will differ for the squatter settlements and those settlements that occupy the state lands or those under customary community lease arrangements.

For each location, the analysis first focuses on space-access configurations and how outdoor space is accessed. Then, a set of land rights held or claimed by individuals, community and local authorities are presented. The community here refers to the smallest administrative units in Indonesian cities, Rukun Tetangga (RT). Individual stakeholder(s) can be a person or a family which together retain the ownership of land. City authorities also refer to the organisations responsible for supporting the urban communities with water, sanitation and sewerage services. In Makassar, department of Public Works Service (Dinas Perkerjaan Umum) has a lead agency and is responsible for providing essential infrastructure, mostly for the city's formal areas.

Through using this typology matrix as a basis, a range of spatial configurations follows. These comprise configurations where the intervention may not be feasible or sustainablemainly in terms of maintenance considerations (Figure 7, lower left), to those where the sustainability and feasibility of the service delivery will be favourably affected as a result of location choice (Figure 7, upper right). In the latter case, land procurement can also create additional benefits for the larger community. 


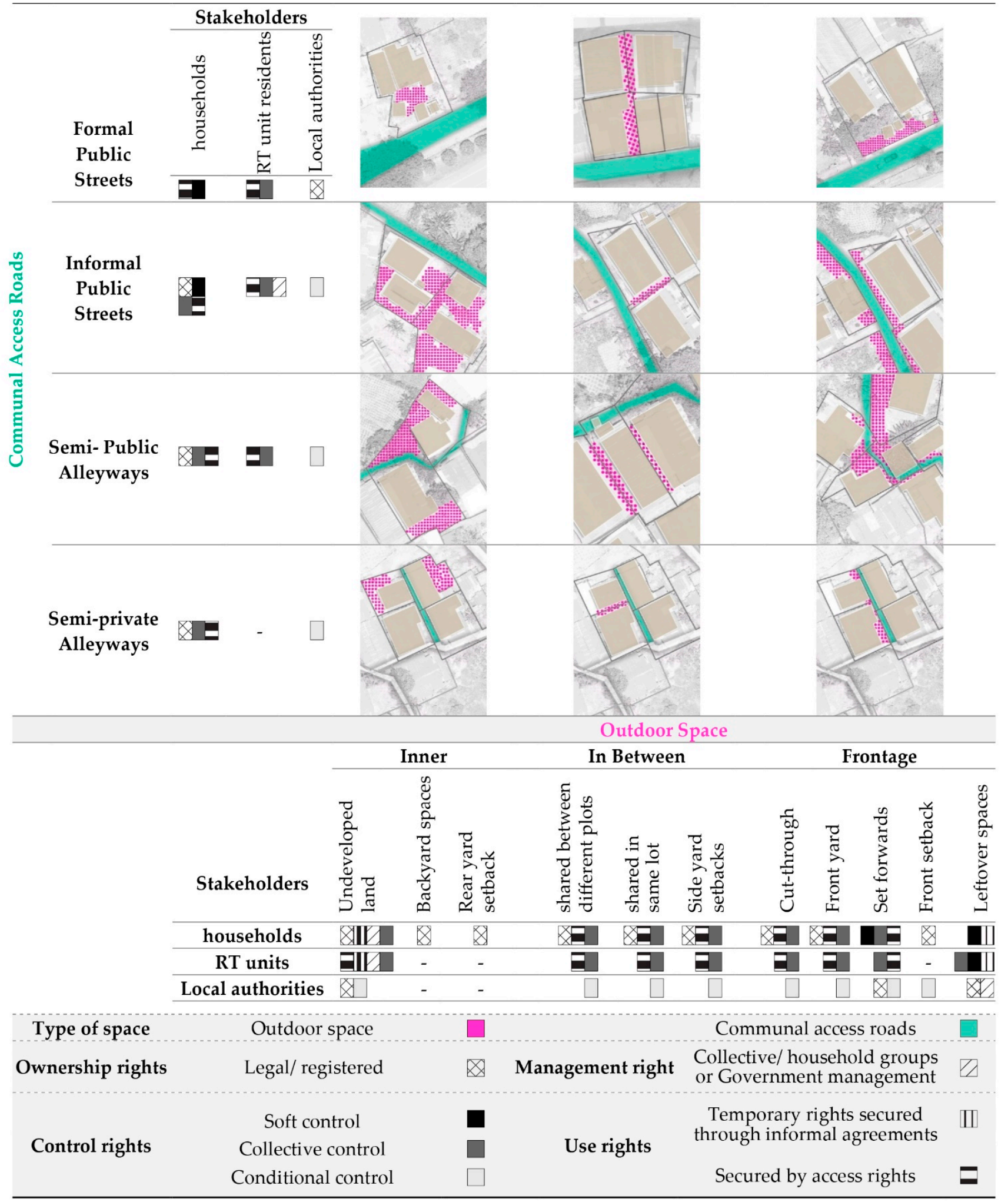

Figure 7. Spatial matrix and Powergram of land rights, developed based on McGlynn and Murrain [42].

\section{Conclusions and Future Research: What Does this Analysis Mean for} Infrastructure Retrofit?

As demonstrated, along with different land ownership types in informal settlements, customary and non-formal forms of land tenure [10] can convey varying degrees of control 
and use rights. The type, extent, and power of claimed rights tend to be spatially dependent upon space's position in settlements' spatial configuration (see Figure 7). These rights may not be bound by legal enforceability. However, until we recognise the agency of rights-holders and the long-term effect of the claimed rights on the intervention, we will struggle to find feasible and sustainable solutions for infrastructure retrofit. A sustainable retrofit practice is both a product of good design solutions and socially and environmentally conscious decisions about the location of infrastructure elements. Therefore, morphological studies need to include these concerns to contribute to the infrastructure design practice in informal settlements.

Based on our observation in this case study, it becomes apparent that immediate proximity to streets and alleyways can present better opportunities for intervention. Where the land is under the collective control and use rights held by a group of households, service provision initiatives can be designed in a way to share the elements of infrastructure with a larger group of households, and facilitate the infrastructure's servicing capacity more effectively. In this case, balancing the benefits gained by those contributing land (the ownership right-holders) and those who benefit from infrastructure without any land contribution, is imperative to the feasibility of land procurement proposals. Through a better location choice and proper safeguard of the rights, the intervention can generate additional benefits such as widening roads for vehicles, creating communal gathering spaces for community, and integrating the settlement into the broader urban context. Spatial readjustments of existing roads may also facilitate obtaining formal land title, which in turn may be a catalyst for community participation and land contribution. However, households' participation can also be discouraged through the force of economic, social and political circumstances. An example of this is where households refuse to contribute land for infrastructure as they anticipate receiving land sale compensation for urban development projects.

This morphological understanding must be considered as an informative tool to aid bottom-up, community-driven approaches to infrastructure provision and safeguarding the rights of those in vulnerable situations. Many questions remain unanswered and are, therefore, recommended as topics for future research in this area: how do individual, collective or communal forms of land rights respond to the land procurement proposals for infrastructure provision? How can these spatial and typological studies of the existing, inform co-designing infrastructure with communities and other stakeholders? How can the infrastructure design practice safeguard the formal and informal land rights, and at the same time provide more agency for the rights-holders?

We conclude by highlighting the need for more flexible land procurement strategies for service delivery at the city level and calling for alternative arrangements for securing the land for public infrastructure. Freeing up the regulations around city authorities' legal-operational context will enable a service provision mechanism that safeguards the existing rights whilst efficiently respond to sanitation improvement demands. These alternative arrangements are often available in the context but remain unrecognised by local authorities.

Author Contributions: Conceptualization, M.M.; Methodology, M.M.; Formal Analysis, M.M.; Data Curation, M.M.; Original Draft Preparation, M.M.; Review \& Editing, M.M. and D.R.-L.; Visualization, M.M.; Supervision, D.R.-L. All authors have read and agreed to the published version of the manuscript.

Funding: This research was funded by Monash University (MDS) and Revitalization of Informal Settlements and their Environment (RISE Ph.D. scholarship).

Institutional Review Board Statement: The study was conducted according to the guidelines of the Declaration of Helsinki, and approved by the Monash University Human Research Ethics Committee (Project Number: 9396; 25 March 2019).

Informed Consent Statement: Informed consent was obtained from all subjects involved in the study. 
Acknowledgments: This paper is derived in part from a broader Ph.D. research by the first author at Monash University. The authors wish to thank Michaela Prescott for her time and helpful suggestions on the first draft of this paper and Mohamed El-Sioufi for his insightful comments on the broader research. The authors would also like to thank anonymous reviewers and Academic Editor for their time, insightful suggestions and constructive comments.

Conflicts of Interest: The authors declare no conflict of interest. The funders had no role in the design of the study; in the collection, analyses, or interpretation of data; in the writing of the manuscript, or in the decision to publish the results.

\section{References}

1. Owen, C.; Dovey, K.; Raharjo, W. Teaching Informal Urbanism: Simulating Informal Settlement Practices in the Design Studio. J. Archit. Educ. 2013, 67, 214-223. [CrossRef]

2. Jones, P. Formalizing the Informal: Understanding the Position of Informal Settlements and Slums in Sustainable Urbanization Policies and Strategies in Bandung, Indonesia. Sustainability 2017, 9, 1436. [CrossRef]

3. Payne, G. Land Tenure and Property Rights: An Introduction. Habitat Int. 2004, 28, 167-179. [CrossRef]

4. Hylton, E.; Charles, K.J. Informal Mechanisms to Regularize Informal Settlements: Water Services in São Paulo's Favelas. Habitat Int. 2018, 80, 41-48. [CrossRef]

5. Basile, P.; Ehlenz, M.M. Examining Responses to Informality in the Global South: A Framework for Community Land Trusts and Informal Settlements. Habitat Int. 2020, 96. [CrossRef]

6. Satterthwaite, D.; Mitlin, D.; Bartlett, S. Is It Possible to Reach Low-Income Urban Dwellers with Good-Quality Sanitation? Environ. Urban. 2015, 27, 3-18. [CrossRef]

7. Ramirez-Lovering, D.; Prescott, M.; Kamalipour, H. RISE: A Case Study for Design Research in Informal Settlement Revitalisation Interdisciplinary Design Research in Informal Settlements; The University of Sydney: Sydney, Australia, 2018; pp. 461-478.

8. Ramirez-Lovering, D.; Zamudio, R.M.; Arifin, H.S.; Kaswanto, R.L.; Simarmata, H.A.; Marthanty, D.R.; Farrelly, M.; Fowdar, H.; Gunn, A.; Holden, J. Pulo Geulis Revitalisation 2045: Urban Design and Implementation Roadmap; Australian-Indonesia Centre (AIC): Australia, 2019; p. 140. Available online: https://research.monash.edu/en/publications/pulo-geulis-revitalisation-2045-urbandesign-and-implementation-r (accessed on 6 March 2020).

9. Njiru, C.; Smout, I.; Sansom, K. Managing Water Services through Service Differentiation and Pricing in an African City. Water Environ. J. 2001, 15, 277-281. [CrossRef]

10. Payne, G. Urban Land Tenure Policy Options: Titles or Rights? Habitat Int. 2001, 25, 415-429. [CrossRef]

11. Murungi, C.; Blokland, M.W. Assessment of Tools in Use by the National Water and Sewerage Corporation to Improve Water and Sanitation Services to the Slums of Kampala, Uganda. Int. J. Water 2016, 10, 192-212. [CrossRef]

12. Van Welie, M.J.; Truffer, B.; Gebauer, H. Innovation Challenges of Utilities in Informal Settlements: Combining a Capabilities and Regime Perspective. Environ. Innov. Soc. Transit. 2019, 33, 84-101. [CrossRef]

13. Mukhija, V. Upgrading Housing Settlements in Developing Countries. Cities 2001, 18, 213-222. [CrossRef]

14. Roy, A. Urban Informality: Toward an Epistemology of Planning. J. Am. Plann. Assoc. 2005, 71, 147-158. [CrossRef]

15. Dovey, K.; King, R. Forms of Informality: Morphology and Visibility of Informal Settlements. Built Environ. 2011, 37, 11-29. [CrossRef]

16. Wekesa, B.W.; Steyn, G.S.; Otieno, F.A.O. A Review of Physical and Socio-Economic Characteristics and Intervention Approaches of Informal Settlements. Habitat Int. 2011, 35, 238-245. [CrossRef]

17. Jones, P. Searching for a Little Bit of Utopia-Understanding the Growth of Squatter and Informal Settlements in Pacific Towns and Cities. Aust. Plan. 2012, 49, 327-338. [CrossRef]

18. Patel, A.; Lotia, H.; Malik, A.A.; Mundt, M.D.; Lee, H.; Rafiq, M.A. Gendered Impacts of Environmental Degradation in Informal Settlements: A Comparative Analysis and Policy Implications for India, Bangladesh, and Pakistan. J. Comp. Policy Anal. Res. Pract. 2020, 1-17. [CrossRef]

19. Marshall, S.; Çalişkan, O. A Joint Framework for Urban Morphology and Design. Built Environ. 2011, 37, 409-426. [CrossRef]

20. Kamalipour, H. Improvising Places: The Fluidity of Space in Informal Settlements. Sustainability 2020, 12, 2293. [CrossRef]

21. Ribeiro, G.; Srisuwan, A. Urban Development Discourses, Environmental Management and Public Participation: The Case of the Mae Kha Canal in Chiang Mai, Thailand. Environ. Urban. 2005, 17, 171-182. [CrossRef]

22. Ribeiro, G. Urban Makings and the Formalisation of Informal Settlements. In Doing Things with Things: The Design and Use of Everyday Objects; Ashgate Publishing, Ltd.: Farnham, UK, 2006; pp. 225-237.

23. Whittal, J. A New Conceptual Model for the Continuum of Land Rights. S. Afr. J. Geomat. 2014, 3, 21.

24. Barry, M.; Augustinus, C. Property Theory, Metaphors and the Continuum of Land Rights; United Nations Human Settlements Programme (UN-Habitat): Nairobi, Kenya, 2015; p. 64.

25. Secure Land Rights for All; UN-Habitat/Global Land Tools Network (Ed.) United Nations Human Settlements Programme, Global Land Tool Network: Nairobi, Kenya, 2008; ISBN 978-92-1-131961-3.

26. UN-Habitat/Global Land Tools Network. Designing and Implementing a Pro-Poor Land Recordation System; United Nations Human Settlements Programme (UN-Habitat): Nairobi, Kenya, 2019. 
27. Augustinus, C.; Lemmen, C.; Van Oosterom, P. Social Tenure Domain Model Requirements from the Perspective of Pro-Poor Land Management. In Proceedings of the 5th FIG Regional Conference, Accra, Ghana, 8-11 March 2006; pp. 8-11.

28. Lemmen, C.; Augustinus, C.; van der Molen, P. The Social Tenure Domain Model—Design of a First Draft Model. In FIG Working Week 2007: Strategic Integration of Surveying Services, 13-17 May, 2007 Hong Kong SAR, China; International Federation of Surveyors (FIG): Copenhagen, Denmark, 2007.

29. Lemmen, C.; Enemark, S.; Mclaren, R.; Antonio, D.; Gitau, J.; Dijkstra, P.; De Zeeuw, K. Guiding Principles for Building Fit-ForPurpose Land Administration Systems in Less Developed Countries: Providing Secure Tenure for All; World Bank: Washington, DC, USA, 2016; p. 26.

30. Paasch, J.; van Oosterom, P.; Lemmen, C. Specialization of the LADM-Modelling of Non-Formal RRR. In LADM2013, 5th Land Administration Domain Model Workshop, Kuala Lumpur, Malaysia, 24-25 September, 2013; International Federation of Surveyors (FIG): Copenhagen, Denmark, 2013; p. 21.

31. Paasch, J.M.; van Oosterom, P.; Lemmen, C.; Paulsson, J. Further Modelling of LADM's Rights, Restrictions and Responsibilities (RRRs). Land Use Policy 2015, 49, 680-689. [CrossRef]

32. Lemmen, C.; van Oosterom, P.; Bennett, R. The Land Administration Domain Model. Land Use Policy 2015, 49, 535-545. [CrossRef]

33. Hendriks, B.; Zevenbergen, J.; Bennett, R.; Antonio, D. Pro-Poor Land Administration: Towards Practical, Coordinated, and Scalable Recording Systems for All. Land Use Policy 2019, 81, 21-38. [CrossRef]

34. Peluso, N.L. Whose Woods Are These? Counter-Mapping Forest Territories In Kalimantan, Indonesia. Antipode 1995, $27,383-406$. [CrossRef]

35. Di Gessa, S.; Poole, P.; Bending, T. Participatory Mapping as a Tool for Empowerment: Experiences and Lessons Learned from the ILC Network; ILCIFAD: Rome, Italy, 2008; p. 45.

36. Aditya, T.; Maria-Unger, E.; vd Berg, C.; Bennett, R.; Saers, P.; Lukman Syahid, H.; Erwan, D.; Wits, T.; Widjajanti, N.; Budi Santosa, P.; et al. Participatory Land Administration in Indonesia: Quality and Usability Assessment. Land 2020, 9 , 79. [CrossRef]

37. Martono, D.B.; Aditya, T.; Subaryono, S.; Nugroho, P. The Legal Element of Fixing the Boundary for Indonesian Complete Cadastre. Land 2021, 10, 49. [CrossRef]

38. Meinzen-Dick, R.; Mwangi, E. Cutting the Web of Interests: Pitfalls of Formalizing Property Rights. Land Use Policy 2009, 26, 36-43. [CrossRef]

39. FAO. Land Tenure and Rural Development; FAO: Rome, Italy, 2002; ISBN 92-5-104846-0.

40. Arko-Adjei, A. Adapting Land Administration to the Institutional Framework of Customary Tenure: The Case of Peri-Urban Ghana; Sustainable Urban Areas; IOS Press BV: Amsterdam, The Netherlands, 2011; ISBN 978-1-60750-746-8.

41. Cozzolino, S.; Moroni, S. Multiple Agents and Self-Organisation in Complex Cities: The Crucial Role of Several Property. Land Use Policy 2021, 103, 105297. [CrossRef]

42. McGlynn, S.; Murrain, P. The Politics of Urban Design. Plan. Pract. Res. 1994, 9, 311-319. [CrossRef]

43. Kropf, K. The Handbook of Urban Morphology; Wiley: Chichester, UK, 2017.

44. Moudon, A.V. Urban Morphology as an Emerging Interdisciplinary Field. Urban Morphol. 1997, 1, 3-10.

45. Ribeiro, G. An Ecological Approach to the Study of Urban Spaces: The Case of a Shantytown in Brasilia. J. Archit. Plan. Res. 1997, $14,13$.

46. Jones, P. The Shaping of Form and Structure in Informal Settlements: A Case Study of Order and Rules in Lebak Siliwangi, Bandung, Indonesia. J. Reg. City Plan. 2019, 30, 43-61. [CrossRef]

47. Dovey, K.; Pafka, E.; Ristic, M. Mapping Urbanities: Morphologies, Flows, Possibilities; Routledge: New York, NY, USA, 2018; ISBN 978-1-138-23360-7.

48. Kamalipour, H.; Dovey, K. Incremental Production of Urban Space: A Typology of Informal Design. Habitat Int. 2020, 98 , 102133. [CrossRef]

49. Barquirn, C.; Brook, R.; Puri, R.; Rybczynski, W. How the Other Half Builds, Volume 2: Plots; Minimum Cost Housing Group (MCHG), McGill University School of Architecture: Montreal, QC, Canada, 1984; p. 53.

50. Rybczynski, W.; Bhatt, V.; Alghamdi, M.; Bahamman, A.; Niskier, M.; Pathare, B.; Pirani, A.; Puri, R.; Raje, N.; Reid, P. How the Other Half Builds, Volume 1: Space; Minimum Cost Housing Group (MCHG), McGill University School of Architecture: Montreal, QC, Canada, 1986; p. 86.

51. Bhatt, V.; Navarrete, J.; Friedman, A.; Baharoon, W.; Minhui, S.; Teixeira, R.; Wiedermann, S. How the Other Half Builds, Volume 3: The Self-Selection Process; Minimum Cost Housing Group (MCHG), McGill University School of Architecture: Montreal, QC, Canada, 1990; p. 44.

52. Kropf, K. Aspects of Urban Form. Urban Morphol. 2009, 13, 105-120.

53. Hillier, B.; Greene, M.; Desyllas, J. Self-Generated Neighbourhoods: The Role of Urban Form in the Consolidation of Informal Settlements. Urban Des. Int. 2000, 5, 61-96. [CrossRef]

54. Moudon, A.V. Getting to know the built landscape: Typomorphology. In Ordering Space: Types in Architecture and Design; Frank, K.A., Schneekloth, L.H., Eds.; Van Nostrand Reinhold: New York, USA, 1994; pp. 289-311.

55. Dovey, K. Urban Design Thinking: A Conceptual Toolkit; Bloomsbury Publishing: London, UK, 2016; ISBN 1-4725-6804-4.

56. Stefanakis, A. The Role of Constructed Wetlands as Green Infrastructure for Sustainable Urban Water Management. Sustainability 2019, 11, 6981. [CrossRef] 
57. Al'Afghani, M.; Paramita, D.; Mitchell, C.; Ross, K. Review of Regulatory Framework for Local Scale "Air Limbah"; Center for Regulation, Policy and Governance, Universitas Ibn Khaldun Bogor and Institute for Sustainable Futures (ISF), University of Technology Sydney (UTS): Sydney, Australia, 2015; p. 86.

58. Al'Afghani, M.M.; Kohlitz, J.; Willetts, J. Not Built to Last: Improving Legal and Institutional Arrangements for Community-Based Water and Sanitation Service Delivery in Indonesia. Water Altern. 2019, 12, 285-303.

59. Home, R. Land Readjustment as a Method of Development Land Assembly: A Comparative Overview. Town Plan. Rev. 2007, 78, 459-483. [CrossRef]

60. UN-HABITAT. Streets as Tools for Urban Transformation in Slums: A Street-Led Approach to Citywide Slum Upgrading; UN-HABITAT: Nairobi, Kenya, 2012.

61. UN-HABITAT. A Practical Guide to Designing, Planning, and Executing Citywide Slum Upgrading Programmes; UN-HABITAT: Nairobi, Kenya, 2014.

62. Eben Saleh, M.A. The Evolution of Planning \& Urban Theory from the Perspective of Vernacular Design: MOMRA Initiatives in Improving Saudi Arabian Neighbourhoods. Land Use Policy 2001, 18, 179-190. [CrossRef]

63. Malloy, R.P. Private Property, Community Development, and Eminent Domain; Routledge: Oxfordshire, UK, 2016; ISBN 1-315-60222-9.

64. Jones, P. The Emergence of Pacific Urban Villages: Urbanization Trends in the Pacific Islands; Pacific Studies Series; Asian Development Bank: Manila, Philippines, 2016; p. 125.

65. AlSayyad, N.; Roy, A. Urban Informality: Transnational Perspectives from the Middle East, Latin America, and South Asia; The Rowman \& Littlefield Publishing Group: Lanham, Maryland, 2004; pp. 7-30.

66. Madanipour, A. Public and Private Spaces of the City; Routledge: Oxfordshire, UK, 2003; ISBN 0-203-40285-5.

67. Langstraat, F.; Van Melik, R. Challenging the "End of Public Space": A Comparative Analysis of Publicness in British and Dutch Urban Spaces. J. Urban Des. 2013, 18, 429-448. [CrossRef]

68. Németh, J.; Schmidt, S. The Privatization of Public Space: Modeling and Measuring Publicness. Environ. Plan. B Plan. Des. 2011, 38, 5-23. [CrossRef]

69. Kropf, K. Plots, Property and Behaviour. Urban Morphol. 2019, 22, 11.

70. Németh, J.; Schmidt, S. Toward a Methodology for Measuring the Security of Publicly Accessible Spaces. J. Am. Plann. Assoc. 2007, 73, 283-297. [CrossRef]

71. Carmona, M. Contemporary Public Space: Critique and Classification, Part One: Critique. J. Urban Des. 2010, 15, 123-148. [CrossRef]

72. De Magalhães, C. Public Space and the Contracting-out of Publicness: A Framework for Analysis. J. Urban Des. 2010, 15, 559-574 [CrossRef]

73. Home, R. Rights to Land Tenure. In International Encyclopedia of Housing and Home; Smith, S.J., Ed.; Elsevier: San Diego, CA, USA, 2012; pp. 182-186. ISBN 978-0-08-047171-6.

74. Abwe, F. A Web of Relations: Co-Production Arrangements in Urban Sanitation Infrastructure Provision in Informal Settlements in Arusha City, Tanzania. Ph.D. Thesis, University of Cape Town, Cape Town, South Africa, 2019.

75. Scott, P.; Cotton, A.; Sohail Khan, M. Tenure Security and Household Investment Decisions for Urban Sanitation: The Case of Dakar, Senegal. Habitat Int. 2013, 40, 58-64. [CrossRef]

76. Scott, P.; Cotton, A.; Sohail, M. Using Tenure to Build a "Sanitation Cityscape": Narrowing Decisions for Targeted Sanitation Interventions. Environ. Urban. 2015, 27, 389-406. [CrossRef]

77. Kellett, P.; Tipple, A.G. The Home as Workplace: A Study of Income-Generating Activities within the Domestic Setting. Environ. Urban. 2000, 12, 203-214. [CrossRef]

78. Tipple, G. The Place of Home-Based Enterprises in the Informal Sector: Evidence from Cochabamba, New Delhi, Surabaya and Pretoria. Urban Stud. 2005, 42, 611-632. [CrossRef] 